\title{
RANCANG BANGUN PROTOTYPE SISTEM SMART PARKING BERBASIS ARDUINO DAN PEMANTAUAN MELALUI SMARTPHONE
}

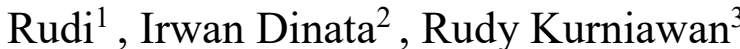 \\ 1,2,3 Jurusan Teknik Elektro Fakultas Teknik - Universitas Bangka Belitung \\ E-mail: rudisanjaya199493@gmail.com, babel_milano@yahoo.com,rudy14k@gmail.com
}

\begin{abstract}
This design Smart Parking aims to design a microcontroller device that is Smart Parking that can inform and direct the driver to the empty parking area. The parking lot used as the research object consists of several parking locations with the capacity of several vehicles, but this study only selects some parking slots as samples. In this design has several common parts used, namely ultrasonic sensors HC-SR04, Arduino Mega, PC / laptop, LCD (Liquid Cristal Display) and IOT (Internet Of Things) research indicates that the LCD will show several parking slots already occupied and Some empty parking slots and monitoring via Smartphone using the Blynk app. As for the crossbar entrance of the parking area using a tool that is servo, and Arduino UNO as the operation of the parking doorstop. In this design the distance of the parking sensor below $6 \mathrm{~cm}$ indicates that parking slots are occupied and above 6cm indicating the parking slot conditions available on LCD and Blynk applications. As for servo bar entry detects the car at a distance below $5 \mathrm{~cm}$ servo will open with delay of 3 seconds and if above $5 \mathrm{~cm}$ indicates that there is no car in front of the sensor bar.
\end{abstract}

Keywords: Arduino, Blynk, Smart Parking

\section{INTISARI}

Perancangan Smart Parking bertujuan untuk merancang suatu alat mikrokontroler yaitu Smart Parking yang dapat menginformasikan dan mengarahkan pengendara mobil ke area parkir yang kosong. Lahan parkir yang dijadikan sebagai objek penelitian terdiri dari beberapa lokasi parkir dengan kapasitas beberapa kendaraan, namun penelitian ini hanya memilih bebarapa slot parkir sebagai sampel. Pada perancangan ini memiliki beberapa bagian umum yang digunakan, yaitu sensor ultrasonik HC-SR04, Arduino Mega, PC/laptop, LCD (Liquid Cristal Display) dan IOT (Internet Of Things) penelitian menunjukkan bahwa LCD akan menampilkan beberapa slot parkir yang sudah terisi dan beberapa lagi slot parkir yang kosong dan pemantauan melalui Smartphone dengan menggunakan aplikasi Blynk. Sedangkan untuk bagian palang pintu masuk area parkir menggunakan alat yaitu servo, dan Arduino UNO sebagai pengoperasian palang pintu parkir tersebut. Pada perancangan ini menghasilkan jarak pada sensor parkir di bawah $6 \mathrm{~cm}$ menandakan bahwa keadaan slot parkir terisi dan di atas $6 \mathrm{~cm}$ menandakan keadaan slot parkir tersedia pada LCD dan aplikasi Blynk tersebut. Sedangkan untuk servo palang masuk mendeteksi mobil pada jarak di bawah $5 \mathrm{~cm}$ servo akan terbuka dengan delay 3 detik dan jika di atas $5 \mathrm{~cm}$ menandakan bahwa tidak ada mobil di depan palang sensor.

Kata Kunci : Arduino, Blynk, Smart Parking

\section{PENDAHULUAN}

Di Indonesia sangat jarang dibahas mengenai teknologi Smart Parking, terutama area khusus seperti gedung-gedung bertingkat seperti pusat pembelanjaan, rumah sakit, bandara, sekolah dan perkantoran. Salah satu perkembangan teknologi dalam bidang transportasi yang dapat kita temukan adalah sistem pelayanan parkir. Saat ini perparkiran dalam suatu gedung sudah mulai menggunakan sistem otomatisasi dalam pengoperasiannya, tetapi penggunaan parkir masih saja terkendala atau kesulitan dalam mencari tempat parkir yang kosong dengan mengelilingi area parkir sehingga kurang efisien dan membutuhkan waktu yang lama untuk memarkirkan kendaraan. Jika proses pelayanan tersebut dapat digantikan dengan menggunakan sistem yang lebih maju lagi maka akan sangat menguntungkan bagi pengguna parkir, baik itu untuk perusahaan besar atau tempat umum lainnya. Berdasarkan hal tersebut maka peneliti merasa perlu membuat suatu alat kendali parkir cerdas (smart parking) dengan 
menggunakan mikrokontroler sebagai otak pengendalian. Komponen yang digunakan dalam pembuatan alat kendali sistem parkir sangat banyak di pasaran. Rangkaian yang digunakan meliputi beberapa komponen seperti sensor ultrasonik, mikrokontroler, kabel jumper, LCD grafik dan lain sebagainya.

Penelitian yang akan dilakukan memiliki beberapa perbedaan dari penelitian-penelitian terdahulu, yaitu tempat pelaksanaan, jenis peralatan, sensor dan proses yang akan dilakukan. Penelitian ini dilakukan guna merancang dan membuat suatu sistem smart parking yang dapat diketahui oleh pengguna parkir yang ingin memarkirkan kendaraannya dan memonitoring area parkir sebelum memasuki area parkir. Untuk melihat slot parkir tersebut ada yang kosong atau tidak sebelum memasuki area parkir dapat dipantau melalui Smartphone menggunakan aplikasi Blynk.

\section{DASAR TEORI}

\section{A. Mikrokontroller}

Mikrokontroler adalah sebuah chip yang berfungsi sebagai pengendali rangkaian elektronik dan umumnya dapat menyimpan program umumnya terdiri dari CPU (Central Processing Unit), memori, I/O tertentu dan unit pendukung seperti Analog-to-Digital Converter (ADC) yang sudah terintegrasi di dalamnya.

\section{B. Arduino Mega 2560}

Arduino Mega 2560 adalah merupakan board mikrokontroler berbasis ATMega 2560. Modul ini memiliki 54 digital input/output dimana 14 digunakan untuk PWM output dan 16 digunakan sebagai analog input, 4 untuk UART, $16 \mathrm{MHz}$ osilator kristal, koneksi USB, power jack, ICSP Header, dan tombol reset. Modul ini memiliki segala yang dibutuhkan untuk memprogram mikrokontroler seperti kabel USB dan sumber daya melalui adaptor ataupun battery.

Arduino Mega 2560 memiliki sejumlah fasilitas untuk berkomunikasi dengan komputer, Arduino lain, atau mikrokontroler lainnya. ATmega2560 ini menyediakan empat UART hardware untuk komunikasi serial. (LED) LightEmitting Diode akan berkedip ketika data sedang dikirim melalui ATmega8U2/ ATmega16U2 koneksi chip dan USB ke komputer.

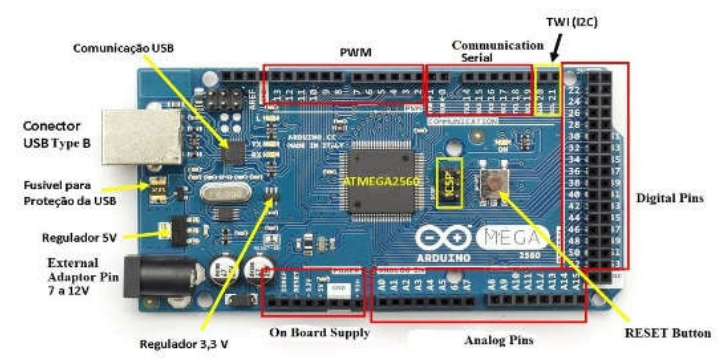

Gambar 1. Arduino Mega 2560

\section{Wifi Module ESP8266}

Modul wireless ESP8266 merupakan modul low-cost Wifi dengan dukungan penuh untuk penggunaan TCP/IP. Modul ini di produksi oleh Espressif Chinese Manufacturer. Pada tahun 2014, AI-Thinker manufaktur pihak ketiga dari modul ini mengeluarkan modul ESP-01, modul ini menggunakan AT-Command untuk konfigurasinya. Modul wireless ESP8266 yang digunakan pada penelitian ini memiliki firmware bawaan pabrik yang mendukung perintah ATCommand.

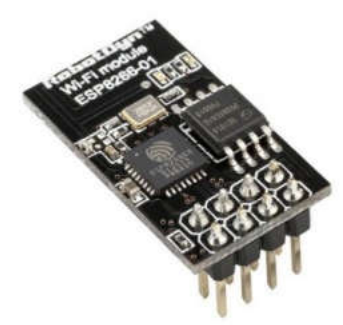

Gambar 2. Wifi module ESP8266

\section{Sensor Ultrasonik HC-SR04}

Sensor ultrasonik merupakan sensor yang bekerja dengan cara memancarkan suatu gelombang dan kemudian menghitung waktu pantulan gelombang tersebut. Kelebihan sensor ini ialah hanya membutuhkan 1 sinyal, selain jalur 5V dan ground. Sensor ultrasonik mendeteksi jarak obyek dengan cara memancarkan gelombang ultrasonik $(40 \mathrm{KHz})$ kemudian mendeteksi pantulannya. Sensor PING memancarkan gelombang ultrasonik sesuai dengan kontrol dari mikrokontroler pengendali. Sensor ini memiliki 4 pin yang harus dihubungkan ke mikrokontroler, yaitu pin Vcc, pin ground, pin trigger, dan pin echo. Pin Vcc dihubungkan ke sumber tegangan $5 \mathrm{~V}$, pin ground dihubungkan ke negatif dari sumber tegangan, sedangkan pin trigger dan echo dihubungkan pada port digital mikrokontroler. 


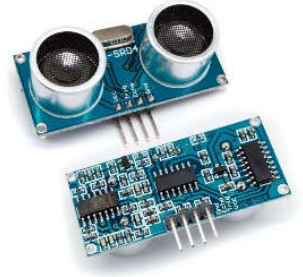

Gambar 3. Sensor Ultrasonik

\section{E. Motor Servo}

Motor servo yang digunakan adalah Towerpro MG995 yang memiliki masukan tegangan $5 \mathrm{~V}$ dan memiliki putaran maksimal $180^{\circ}$. Motor servo ini memiliki 3 masukan, yaitu power, ground dan control.

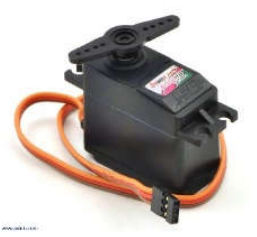

Gambar 4. Motor Servo

\section{F. LCD (Liquid Crystal Display)}

LCD dikembangkan untuk modul Arduino yang kompatibel, untuk menyediakan antarmuka user-friendly yang memungkinkan pengguna untuk pergi melalui menu, membuat pilihan dan lain-lain, terdiri dari 1602 karakter putih LCD dengan latar belakang biru. Tombol terdiri dari 5 tombol - reset, atas, kanan, bawah dan kiri. Untuk menyimpan pin I/O digital, antarmuka keypad hanya menggunakan satu saluran ADC. Nilai tegangan dari setiap keypad pada saat membaca adalah $5 \mathrm{~V}$.

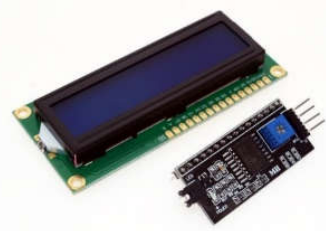

Gambar 5. LCD

\section{G. Internet of Things (IoT)}

Internet of Things (IoT) pertama kali diperkenalkan oleh Kevin Ashton pada tahun 1999. Meski telah diperkenalkan sejak 15 tahun yang lalu, hingga kini belum ada sebuah konsensus global mengenai definisi IoT. Namun secara umum konsep IoT diartikan sebagai sebuah kemampuan untuk menghubungkan objek-obek cerdas dan memungkinkannya untuk berinteraksi dengan objek lain, lingkungan maupun dengan peralatan komputasi cerdas lainnya melalui jaringan internet. IoT dalam berbagai bentuknya telah mulai diaplikasikan pada banyak aspek kehidupan manusia. (Meutia, 2015)

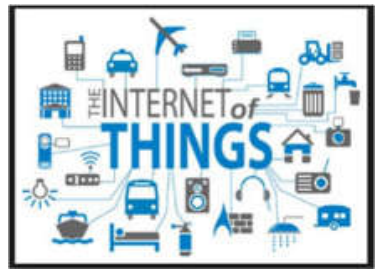

Gambar 6. Internet of Things

\section{H. Android}

Menurut Nazrudin Safaat H (2011 : 1)"Android adalah sebuah sistem operasi untuk perangkat mobile berbasis Linux yang mencakup sistem operasi, middleware, dan aplikasi." Android adalah sistem operasi untuk telepon seluler yang berbasis Linux. Android menyediakan platform terbuka bagi para pengembang untuk membuat aplikasi mereka sendiri. Pada awalnya dikembangkan oleh Android Inc, sebuah perusahaan pendatang baru yang membuat perangkat lunak untuk ponsel yang kemudian dibeli oleh Google Inc. Untuk pengembangannya, dibentuklah Open Handset Alliance (OHA), konsorsium dari 34 perusahaan perangkat keras, perangkat lunak, dan telekomunikasi termasuk Google, HTC, Intel, Motorola, Qualcomm, T-Mobile, dan Nvidia.

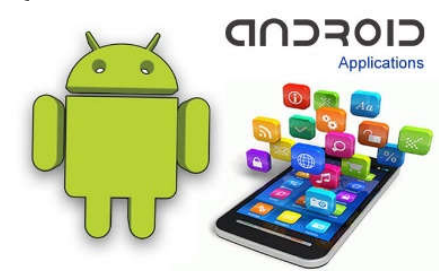

Gambar 7. Sistem operasi android

\section{Aplikasi Blynk}

Blynk adalah platform dengan iOS dan android aplikasi untuk mengontrol Arduino, raspberry $\mathrm{Pi}$ dan sejenisnya melalui internet. Dalam hal ini adalah dashboard digital, dimana pengguna akan membangun sebuah antarmuka grafis untuk proyeknya dengan menarik dan dapat menggunakan widget . Hal ini benar-benar sederhana untuk mengatur semuanya sehingga pengguna akan mulai bermain-main dalam waktu yang relatif singkat. Blynk tidak terikat dengan beberapa board tertentu atau shield. Sebaliknya, Blynk mendukung hardware pilihan pengguna seperti Arduino atau Raspberry Pi yang terhubung dengan internet melalui Wi-Fi, Ethernet atau chip ESP8266. 


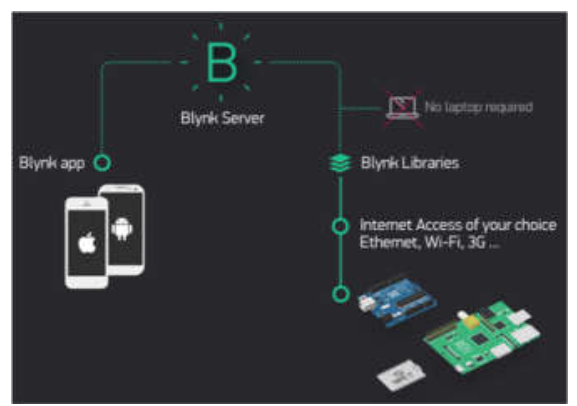

Gambar 8. Aplikasi dan sistem kerja Blynk

\section{METODE PENELITIAN}

\section{A. Langkah Penelitian}

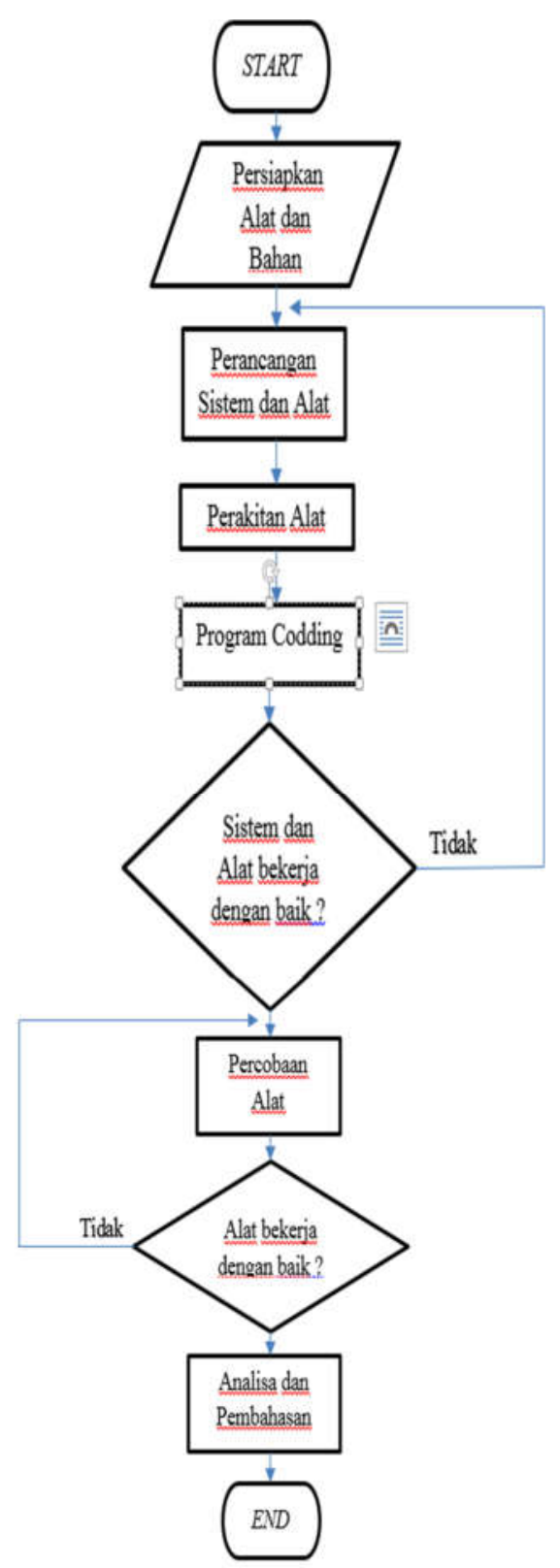

Gambar 9. Langkah penelitian
B. Perancangan Sistem

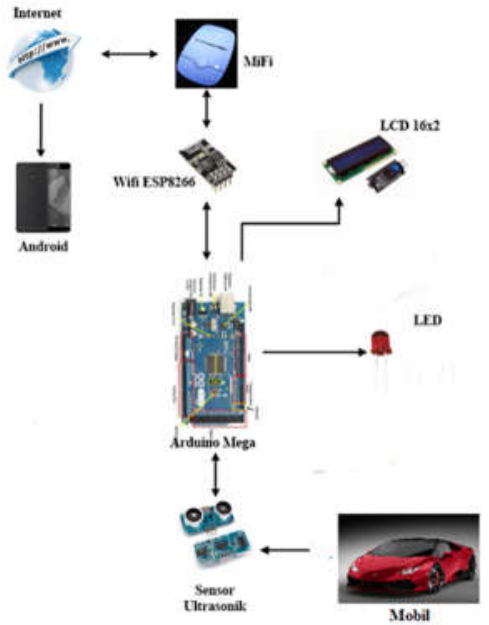

Gambar 10. Perancangan sistem smart parking

Dari Gambar 10 dapat dijelaskan sebagai berikut :

1. Wifi modul menghubungkan perangkat ke internet.

2. Arduino membaca user id dan password dari hotspot/wifi yang digunakan.

3. Setelah terkoneksi maka akan mulai mengaktifkan sensor ultrasonik.

4. Arduino membaca perubahan nilai pada sensor ultrasonik.

5. Output berupa angka dan tulisan yang ditampilkan pada LCD.

6. Setelah itu data output dikirimkan ke database pada aplikasi Blynk di smartphone melalui internet.

7. Smartphone dihubungkan pada aplikasi Blynk melalui internet.

Semua data output kemudian akan dipantau melalui smartphone secara real time melalui aplikasi Blynk yang telah terintegrasi dengan Arduino.

C. Perancangan Sistem Palang Pintu

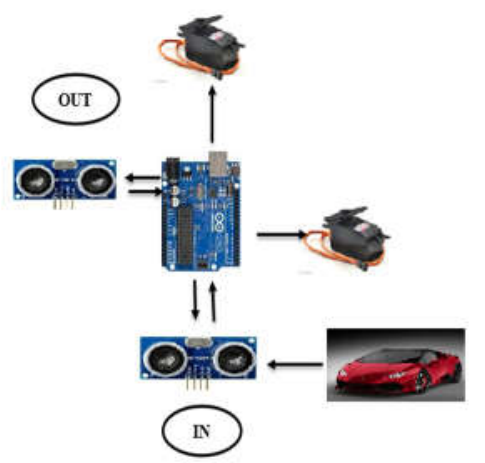

Gambar 11. Perancangan sistem palang pintu 

berikut :

Dari Gambar 11 dapat dijelaskan sebagai

1. Arduino membaca masukan dari sensor.

2. Setelah itu data masukan dari sensor di proses oleh Arduino.

3. Lalu arduino mengirim perintah ke servo untuk membuka palang pintu.

4. Setelah penghalang di depan sensor kosong

5. Maka Arduino membaca masukan dari sensor.

6. Lalu arduino memerintahkan servo untuk menutup palang pintu.

D. Perancangan Sistem Keseluruhan

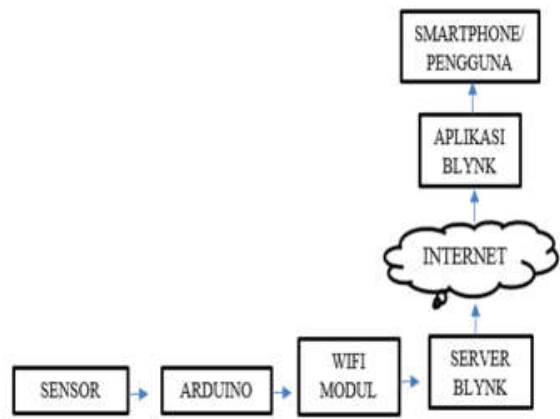

Gambar 12. Perancangan sistem smart parking berikut:

Dari Gambar 12 dapat dijelaskan sebagai

1. Sensor membaca masukan dari halangan yang ada di depan sensor

2. Lalu sensor tersebut mengirim data ke arduino untuk di proses

3. Arduino mendapat jaringan dari modul wifi tersebut

4. Lalu modul wifi mengirim data ke server Blynk

5. Setelah di terima dari server Blynk maka akan terkoneksi melalui jaringan internet yang sudah tersedia

6. Setelah terkoneksi ke internet maka data tersebut di proses oleh aplikasi Blynk tersebut

7. Setelah itu smartphone membuka aplikasi Blynk tersebut untuk melihat slot parkir mana yang masih kosong.

\section{HASIL DAN PEMBAHASAN}

\section{A. Desain Prototype Keseluruhan}

Berikut ini adalah gambar dari desain prototype smart parking yang sudah dirancang seperti yang terlihat pada Gambar 13.

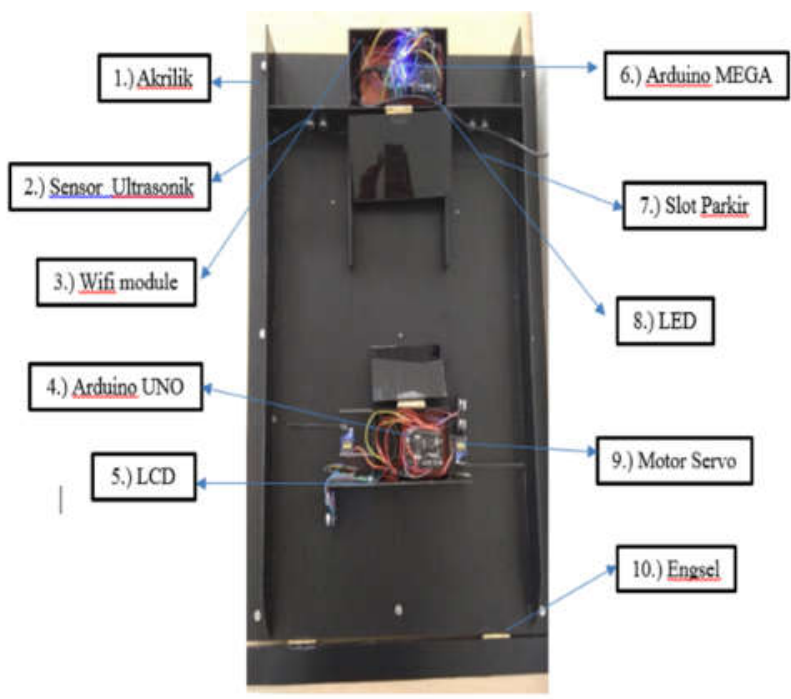

Gambar 13. Desain Prototype Smart Parking

Gambar 13 menjelaskan pada saat mobil akan memasuki area parkir maka terlebih dahulu melewati plang yang menggunakan plang otomatis dan melihat di LCD atau aplikasi Blynk untuk mengetahui slot parkir mana yang kosong, jika kendaraan berada di depan sensor maka plang akan naik, jika kendaraan sudah melewati plang tersebut maka plang akan otomatis akan tertutup kembali dan mobil akan parkir ke area yang kosong. Begitu juga pada saat kendaraan lain ingin memarkirkan kendaraannya terlebih dahulu pengguna membuka aplikasi blynk yang ada di smartphone untuk melihat slot parkir mana yang masih kosong.

\section{B. Pengujian Alat}

Pengujian pertama dilakukan dengan mengecek fungsi masing-masing sensor serta display yang digunakan. Kemudian dilanjutkan dengan pengujian wiring rangkaian. Pada proses ini sangat sering terjadi kesalahan yang membuat alat tidak bekerja sehingga harus dilakukan proses troubleshooting untuk mencari dimana letak kesalahan atau error yang terjadi.

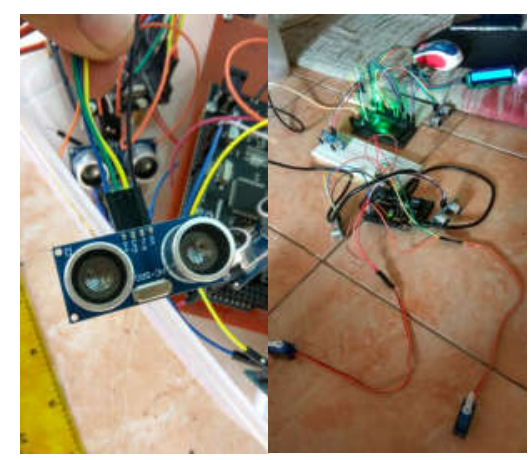

Gambar 14. Pengujian peralatan dan sensor 
Setelah rangkaian dan sensor sudah berjalan dengan baik maka kemudian dilanjutkan dengan menempatkan semuanya ke dalam miniatur akrilik yang telah disediakan. Pada miniatur tersebut kemudian dibor untuk masing-masing peralatan dan sensor.

Kemudian setelah pembuatan kedudukan selesai, dilanjutkan dengan penempatan peralatan sesuai dengan kedudukan masingmasing. Setelah itu dilakukan kembali proses pengujian dengan tujuan agar peralatan tetap dapat berfungsi setelah ditempatkan ke miniatur tersebut.

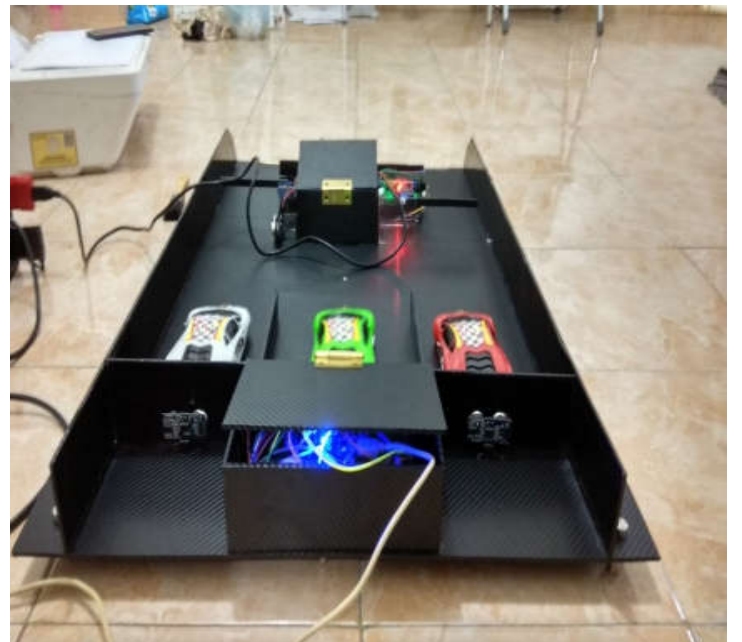

Gambar 15. Rancangan Smart Parking

\section{Uji Monitor Smart Parking}

Setelah pengujian peralatan dilakukan sehingga alat berfungsi seperti yang diharapkan. Kemudian dilakukan pemasangan peralatan pada papan prototype smart parking. Selanjutnya proses monitoring melalui Smartphone dengan mengklasifikasikan jarak pada sensor yang telah ditentukan. Selain itu, pada penelitian ini digunakan motor servo untuk bagian palang dimana berfungsi untuk membuka palang ketika mobil berada pas di depan sensor. Ketika mobil berada pada posisi depan sensor maka plang akan naik dan ketika mobil sudah berjalan maka palang akan tertutup kembali. Ketika mobil masuk ke slot 1 maka tampilan di aplikasi Blynk tersebut dapat dilihat pada Gambar 16.

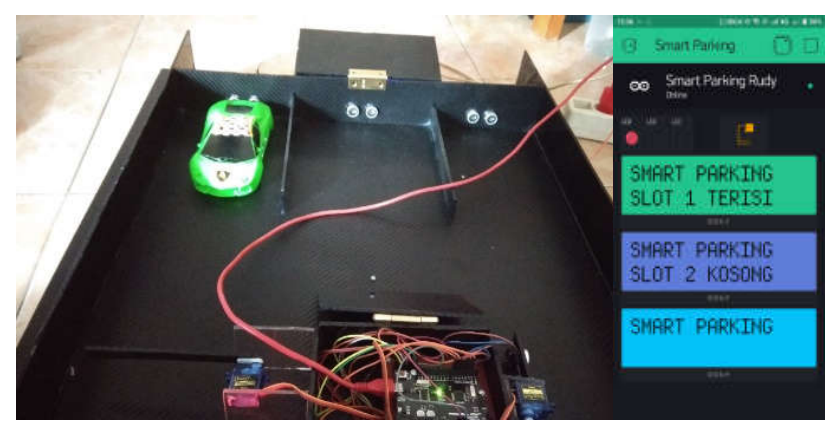

Gambar 16. Monitoring Smart Parking pada saat slot 1 terisi

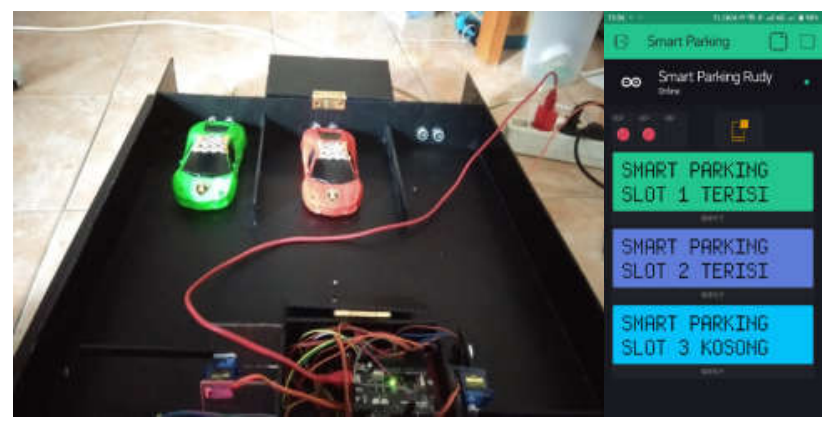

Gambar 17. Monitoring Smart Parking pada saat slot 1 dan 2 terisi

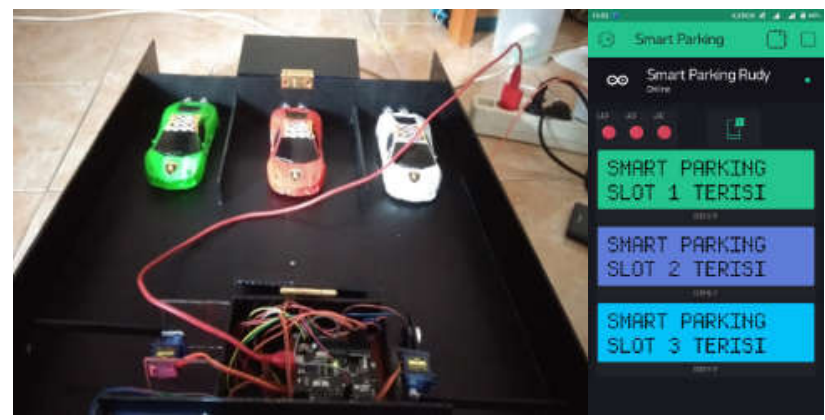

Gambar 18. Monitoring Smart Parking pada saat semua slot terisi

Ketika semua slot kosong maka lampu led di aplikasi Blynk tidak menyala dan slot parkir 1,2 dan 3 kosong dapat dilihat pada Gambar 19.

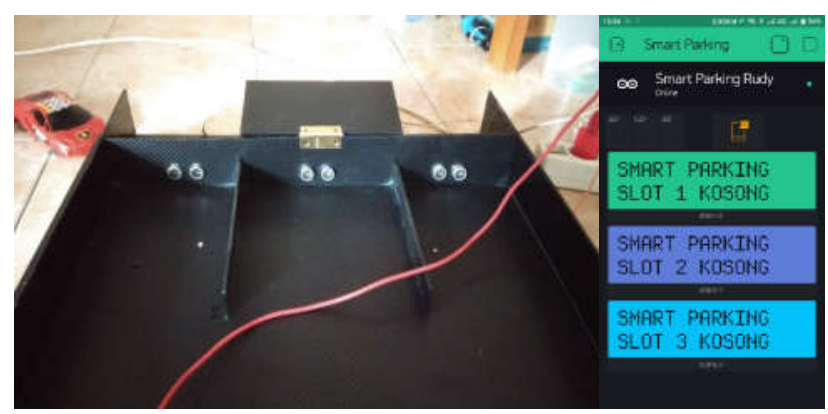

Gambar 19. Monitoring Smart Parking pada saat semua slot kosong 
D. Uji Jarak dan Waktu Pengirim Data Pesan

Tabel 1. Jarak dan waktu pengiriman data pesan ke smartphone

\begin{tabular}{|c|c|c|c|}
\hline No. & Jarak (m) & Waktu Delay & Keterangan \\
\hline $\mathbf{1}$ & 0 & 0,12 & Berhasil \\
\hline 2 & 1 & 0,12 & Berhasil \\
\hline 3 & 5 & 0,13 & Berhasil \\
\hline 4 & 10 & 0,13 & Berhasil \\
\hline $\mathbf{5}$ & 20 & 0,13 & Berhasil \\
\hline 6 & 30 & 0,13 & Berhasil \\
\hline 7 & 40 & 0,13 & Berhasil \\
\hline $\mathbf{8}$ & 50 & 0,13 & Berhasil \\
\hline 9 & 60 & 0,19 & Berhasil \\
\hline 10 & 70 & 0,19 & Berhasil \\
\hline 11 & 80 & 0,19 & Berhasil \\
\hline 12 & 90 & 0,24 & Berhasil \\
\hline 13 & 100 & 0,24 & Berhasil \\
\hline 14 & 150 & 0,24 & Berhasil \\
\hline 15 & 200 & 0,24 & Berhasil \\
\hline 16 & 250 & 0,24 & Berhasil \\
\hline 17 & 300 & 0,52 & Berhasil \\
\hline 13 & 350 & 0,52 & Berhasil \\
\hline 19 & 400 & 0,52 & Berhasil \\
\hline 20 & 450 & 0,58 & Berhasil \\
\hline 21 & 500 & 0,86 & Berhasil \\
\hline 22 & 700 & 1,09 & Berhasil \\
\hline 23 & 850 & 1,12 & Berhasil \\
\hline 24 & 1000 & 1,23 & Berhasil \\
\hline 25 & 5 seterusnva & - & Berhasil \\
\hline
\end{tabular}

Dari Tabel 1 dapat dijelaskan bahwa hasil pengukuran kecepatan pengiriman pada Tabel 1 terdapat 24 pengujian dengan jarak paling jauh $10 \mathrm{~km}$ dengan perkiraan waktu delay 1,23 detik.

Proses pengujian yang dilakukan hanya mencapai jarak $10 \mathrm{~km}$ dan pengujian masih bisa dilakukan tergantung kualitas jaringan di smartphone pengguna itu sendiri, karena berapa pun jarak pengguna dari peralatan Smart Parking selama smartphone masih tersambung dengan jaringan internet, maka pengiriman informasi yang dikirim ke smartphone akan tersampaikan walau terjadinya keterlambatan atau delay yang dipengaruhi kualitas jaringan yang ada di daerah pengguna smartphone.

\section{KESIMPULAN}

Berdasarkan hasil dan pembahasan, maka dapat disimpulkan bahwa:

1. Rancangan prototype smart parking menggunakan Arduino, yang kemudian ditampilkan pada LCD dan pengiriman informasi melalui aplikasi Blynk di Smartphone dapat bekerja dengan baik.

2. Implementasi dari prototype smart parking selanjutnya dapat diterapkan atau dibangun untuk mengatasi persoalan parkir yang ada ditempat parkiran umum.

\section{DAFTAR PUSTAKA}

[1] Bejo, A. (2013). C\&AVR Rahasia Kemudahan Bahasa $C$ dalam MikokontrolerATMega8535. Graha Ilmu, Yogyakarta.

[2] Budiharto, W. (2012). Panduan Praktikum Mikrokontroler AVR ATMega16. PT. Elex Media Komputindo, Jakarta.

[3] Murti, Y. (2016). Rancang Bangun Prototipe Pengendali Peralatan Rumah Tangga Menggunakan Arduino dan Smartphone. Skripsi. Universitas Bangka Belitung. Bangka.

[4] Aji, W. S., Hermawanto, F., Muchlas (2010). "Purwarupa Robot Pemadam Api Dengan Sensor Ultrasonik Dan Ultraviolet Berbasis AT89S52" Tugas Akhir, Universitas Ahmad Dahlan, Yogyakarta.

[5] Sugiharto, A. (2013). Penerapan Dasar Tranduser dan Sensor. Kanisius, Yogyakarta.

[6] http://www.innovativemobility.org/smart_p arking/Smart_Parking.shtml. Innovative Mobility: Smart Parking Management: A Bay Area Rapid Transit (BART) District Parking Field Test and ResearchEvaluation (diakses pada 12 Oktober 2016). 